\title{
Article \\ Chitosan Sensitivity of Fungi Isolated from Mango (Mangifera indica L.) with Anthracnose
}

\author{
Griselda Valenzuela-Ortiz ${ }^{1}$, Soila Maribel Gaxiola-Camacho ${ }^{1}$, Cesar San-Martín-Hernández ${ }^{2} \mathbb{D}$, \\ Miguel Ángel Martínez-Téllez ${ }^{3, *}{ }^{\mathbb{D}}$, Emmanuel Aispuro-Hernández ${ }^{3}{ }^{(\mathbb{B}}$, Jaime Lizardi-Mendoza ${ }^{4}$ (D) \\ and Eber Addí Quintana-Obregón $5, *$ (D)
}

check for

updates

Citation: Valenzuela-Ortiz, G.; Gaxiola-Camacho, S.M.; San-Martín-Hernández, C.; Martínez-Téllez, M.Á.; AispuroHernández, E.; Lizardi-Mendoza, J.; Quintana-Obregón, E.A. Chitosan Sensitivity of Fungi Isolated from Mango (Mangifera indica L.) with Anthracnose. Molecules 2022, 27, 1244. https://doi.org/10.3390/ molecules27041244

Academic Editors: Gianfranco Romanazzi and Silvia Bautista-Baños

Received: 12 January 2022

Accepted: 10 February 2022

Published: 12 February 2022

Publisher's Note: MDPI stays neutra with regard to jurisdictional claims in published maps and institutional affiliations.

Copyright: (C) 2022 by the authors. Licensee MDPI, Basel, Switzerland. This article is an open access article distributed under the terms and conditions of the Creative Commons Attribution (CC BY) license (https:// creativecommons.org/licenses/by/ $4.0 /)$.
1 Facultad de Medicina Veterinaria y Zootecnia, Universidad Autónoma de Sinaloa, Culiacán 80260, Mexico; griseval1993@gmail.com (G.V.-O.); soilagaxiola@uas.edu.mx (S.M.G.-C.)

2 Colegio de Postgraduados, Campus Montecillo, Texcoco 56230, Mexico; sanmartin.cesar@colpos.mx

3 Centro de Investigación en Alimentación y Desarrollo, A.C. Coordinación de Tecnología de Alimentos de Origen Vegetal, Hermosillo 83304, Mexico; eaispuro@ciad.mx

4 Centro de Investigación en Alimentación y Desarrollo, A.C. Coordinación de Tecnología de Alimentos de Origen Animal, Hermosillo 83304, Mexico; jalim@ciad.mx

5 Programa de Investigadoras e Investigadores por México del CONACYT-Centro de Investigación en Alimentación y Desarrollo, A.C. (CIAD), Coordinación de Tecnología de Alimentos de Origen Vegetal, Hermosillo 83304, Mexico

* Correspondence: norawa@ciad.mx (M.Á.M.-T.); eber.quintana@ciad.mx (E.A.Q.-O.) Tel.: +52-(662)-289-2400 (M.Á.M.-T. \& E.A.Q.-O. )

\begin{abstract}
In Mexico, the mango crop is affected by anthracnose caused by Colletotrichum species. In the search for environmentally friendly fungicides, chitosan has shown antifungal activity. Therefore, fungal isolates were obtained from plant tissue with anthracnose symptoms from the state of Guerrero in Mexico and identified with the ITS and $\beta-\mathrm{Tub}_{2}$ genetic markers. Isolates of the Colletotrichum gloeosporioides complex were again identified with the markers ITS, Act, $\beta$-Tub 2, GADPH, CHS-1, CaM, and ApMat. Commercial chitosan (Aldrich, lot \# STBF3282V) was characterized, and its antifungal activity was evaluated on the radial growth of the fungal isolates. The isolated anthracnosecausing species were C. chrysophilum, C. fructicola, C. siamense, and C. musae. Other fungi found were Alternaria sp., Alternaria tenuissima, Fusarium sp., Pestalotiopsis sp., Curvularia lunata, Diaporthe pseudomangiferae, and Epicoccum nigrum. Chitosan showed 78\% deacetylation degree and a molecular weight of $32 \mathrm{kDa}$. Most of the Colletotrichum species and the other identified fungi were susceptible to $1 \mathrm{~g} \mathrm{~L}^{-1}$ chitosan. However, two C. fructicola isolates were less susceptible to chitosan. Although chitosan has antifungal activity, the interactions between species of the Colletotrichum gloeosporioides complex and their effect on chitosan susceptibility should be studied based on genomic changes with molecular evidence.
\end{abstract}

Keywords: phytopathogen; Colletotrichum complex; antifungal; chitosan

\section{Introduction}

Diseases caused by phytopathogenic fungi during pre- and post-harvest storage leads to significant losses for farmers and generate conditions for food insecurity [1]. Farmers have managed to minimize losses in the production of horticultural products with the use of agrochemicals, for example, fungicides such as azoxystrobin, fludioxonil, captan, merivon, imazalil, propiconazole, fosetyl-Al, orthophenylphenol, prochloraz, pyrimethanil, methylthiophanate, thiabendazole, and fludioxonil, among others [1-4]. However, some of the disadvantages of using these products are the resilience that fungi may develop [5], the damage to health, and damage to the environment [6]. This highlights the need to control post and pre-harvest diseases caused by phytopathogens with compounds that contribute to the success of sustainable agriculture and reduce the use of harmful agrochemicals [7]. 
The development of alternatives to traditional fungicides aims to reduce environmentally harmful products to control phytopathogenic fungi [8]. In this regard, some compounds of natural origin, such as essential oils, methanolic extracts, plant extracts, lipoproteins, and chitosan, have shown antifungal effects $[7,9,10]$.

Chitosan is the direct derivative of chitin; it is a natural, biodegradable, non-toxic compound with fungicidal effects that induce defense mechanisms in plant tissues [11]. Likewise, chitosan has been evaluated in phytopathogenic fungi showing its antifungal activity against Fusarium, Rhizopus, Aspergillus, Alternaria, and Colletotrichum [12-15]. The benefits of chitosan in agriculture encourage its use for the pre- and post-harvest control of horticultural fruits [16]. However, the sensitivity of the different fungal strains to chitosan often varies according to intrinsic characteristics proper of each species, e.g., particularities in the cell wall and membrane composition.

One of the most important fruits in Mexico is the mango (Mangifera indica L.), the 2019-year production of 2,089,041 t positioned Mexico as the sixth producer of mango worldwide, where the state of Guerrero is one of the leading producers nationwide [17]. However, farmers in Mexico still report losses related to various fungal diseases, one of them being anthracnose caused by fungi of the Colletotrichum genus $[18,19]$. Earlier studies have shown the antifungal effect of chitosan on Colletotrichum isolates [20], most of them identified as part of the Colletotrichum complexes; nevertheless, there is still little information on the chitosan sensitivity at the level of the Colletotrichum species. A Colletotrichum complex requires identification with the genomic alignment of at least one gene, while species identification requires at least three genes [21]. This research aimed to evaluate the in vitro chitosan sensitivity of fungal isolates obtained from anthracnose injuries in mango from Guerrero, Mexico. The species were identified with seven genes using a genomic alignment approach.

\section{Results and Discussion}

\subsection{Identification of Fungal Isolates}

The sequences of ITS and $\beta$-Tub 2 (first genomic alignment) allowed us to classify the fungal isolates obtained from leaves and fruit into seven main clades consistent of different fungal genera, in which seven isolates belong to the $C$. gloeosporioides complex, the causal agent of anthracnose in mango (Figure 1). Likewise, the non-Colletotrichum fungal isolates found in the present work belong to species associated with mango infections (Figure 1). The second genomic alignment using ITS, Act, $\beta-\mathrm{Tub}_{2}$, GAPDH, CHS- $1, \mathrm{CaM}$, and ApMat sequences from the isolates of the Colletotrichum complex, allowed the identification of four species of the Colletotrichum genera (Figure 2).

Among the isolates belonging to the Colletotrichum complex species, only one was isolated from fruit, while the rest were found in infected leaves. The complexes of C. gloeosporioides are more adapted to infect vegetative tissues than fruit, contrasting, for example, with the C. acutatum complex, which is more adapted to fruit infection [21]. Concerning the fungal identification of mango isolates, earlier Tovar-Pedraza et al. [22], obtained isolates from the $C$. gloeosporioides complex, and found the species $C$. alienum, C. asianum, C. siamense, and $C$. tropicale using Apn2/MAT intergenic spacer sequences. In contrast, our results suggest the species $C$. fructicola, $C$. chrysophilum, C. musae, and C. siamense as causal agents of anthracnosis in mango. These differences may be related to the sample size and the goals of each study. Tovar-Pedraza et al. [22] obtained samples from eight Mexican states (Sinaloa, Nayarit, Colima, Michoacan, Guerrero, Oaxaca, Chiapas, and Veracruz); their goal was to find the distribution of Colletotrichum species in mango, while our study considered samples from one Mexican state (Guerrero) to obtain Colletotrichum isolates from mango for evaluating the sensitivity to chitosan. Additionally, Li et al. [23] reported C. asianum, C. fructicola, and C. siamense on mango in China. Studies on anthracnose disease in mango have shown that the Colletotrichum species belong to the C. gloeosporioides complex, and multiple markers are necessary for proper species identification [24]. 


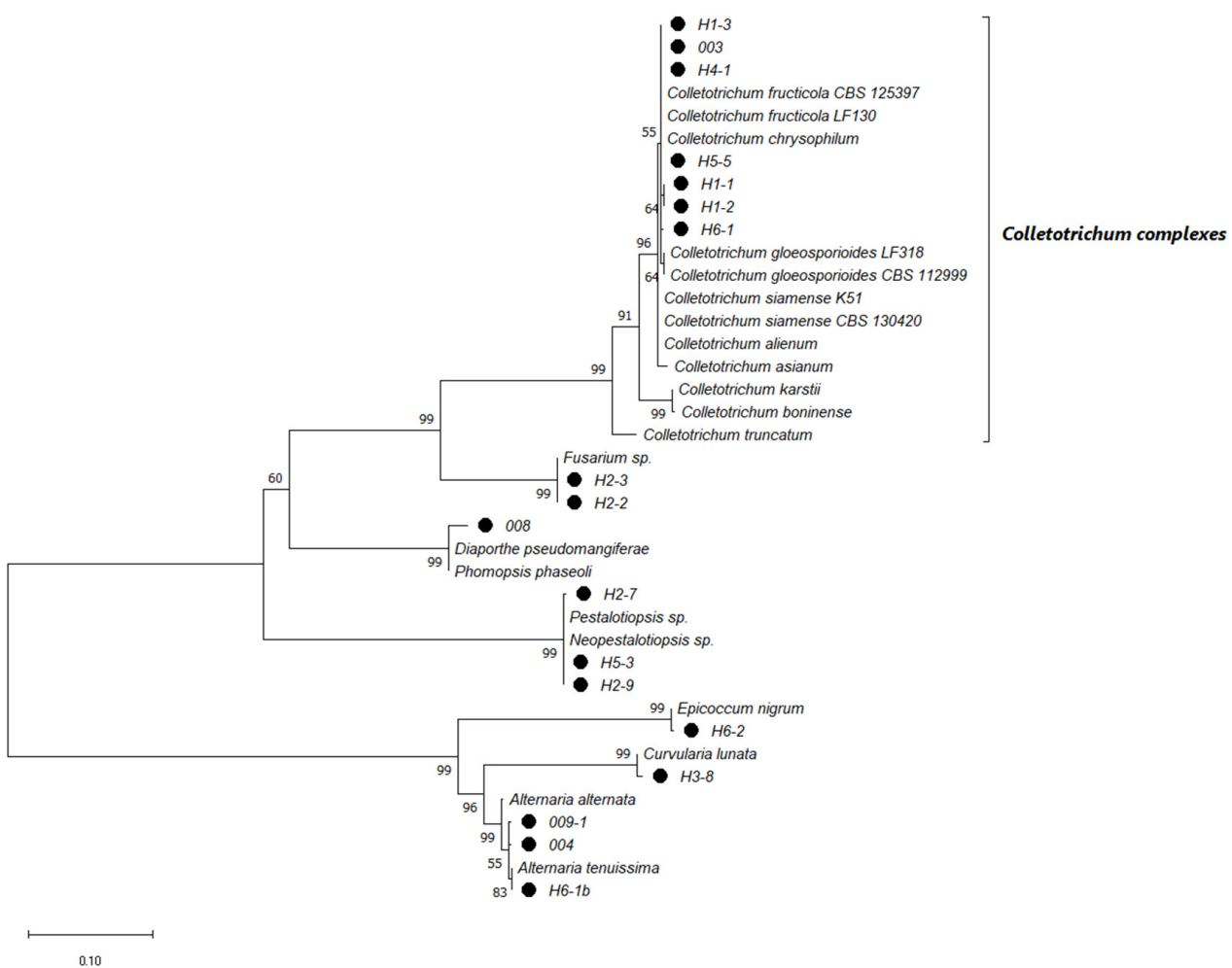

Figure 1. Tree phylogenetic relationship amongst fungi isolated from Mangifera indica L. with anthracnose-like symptoms. Maximum likelihood tree based on combined ITS and $\beta$-Tub $\mathrm{b}_{2}$ sequence data. Black dots show isolates characterized in the present work. Bootstrap support values are displayed at the tree nodes, and the branch lengths and scale bar represent the number of substitutions per site. $\bullet$ Isolates from Guerrero, Mexico.

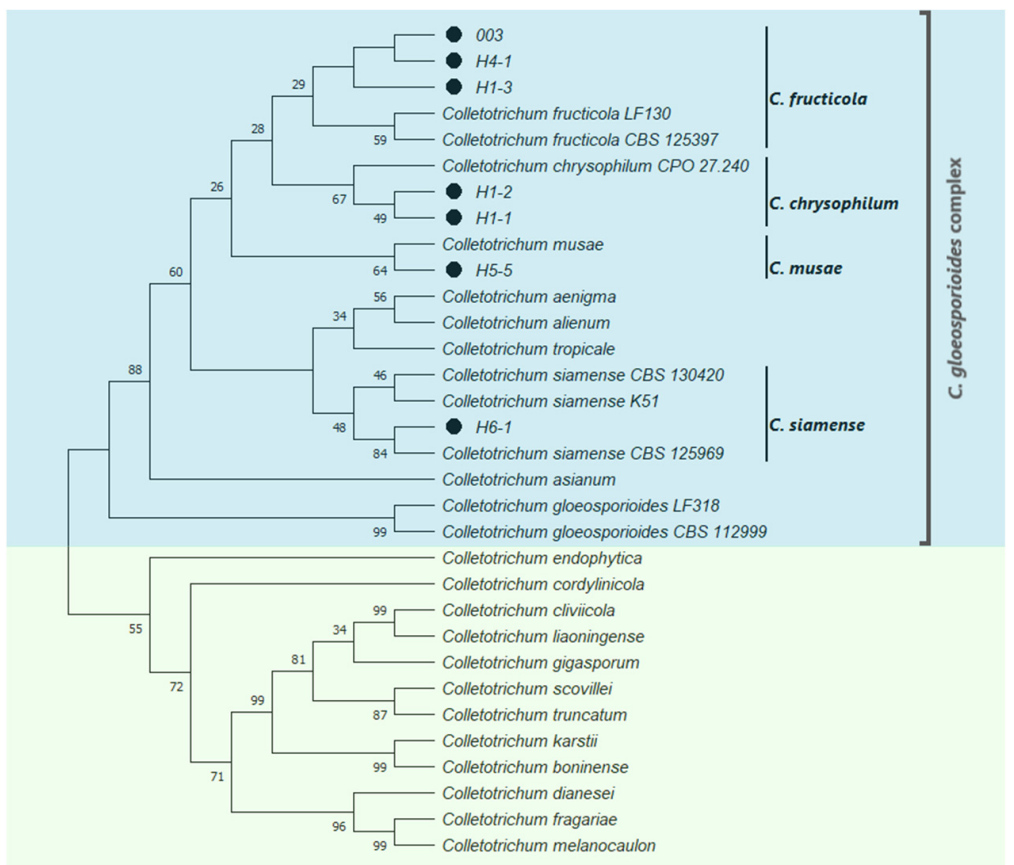

Figure 2. Identification of Colletotrichum species isolated from Mangifera indica L. Bootstrap consensus tree inferred by the maximum likelihood method and general time-reversible model based on the sequences of ITS, Act, $\beta$-Tub 2 , GAPDH, CHS-1, CaM, and ApMat. Bootstrap values next to the branches stand for the percentage of replicate trees in which the associated taxa clustered together (1000 replicates). Black dots show isolates characterized in the present work. 
In addition to the Colletotrichum species related to anthracnose in mango, the other identified fungal isolates belong to six different genera, including Alternaria, Fusarium, Pestalotiopsis, Curvularia, Diaporthe, and Epicoccum (Figure 1). These fungi can act as saprophytes and have been reported to occasionally cause diseases in mango, with some symptoms such as anthracnose [25-30].

\subsection{Chitosan Characterization and Sensitivity of Isolated Fungi}

The FT-IR spectrum corresponding to the chitosan sample (Figure 3) allowed calculating $78.5 \pm 0.1 \%$ degree of deacetylation, and the molecular weight was $32.0 \pm 6.4 \mathrm{kDa}$ using a capillary viscosimeter. Usually, chitosans at the 10-200 kDa range are considered low molecular weight [31]. The degree of deacetylation and the molecular weight is related to the type of biological activity of the chitosan with the fungus and is fully documented; Grande-Tovar et al. [32] summarize the three main mechanisms proposed in the last few years: 1) interaction between amino groups of chitosan with anionic groups on the cell wall surface; 2 ) interaction of the positive amino groups of chitosan with the negative charges of phospholipids; and 3) binding of DNA.

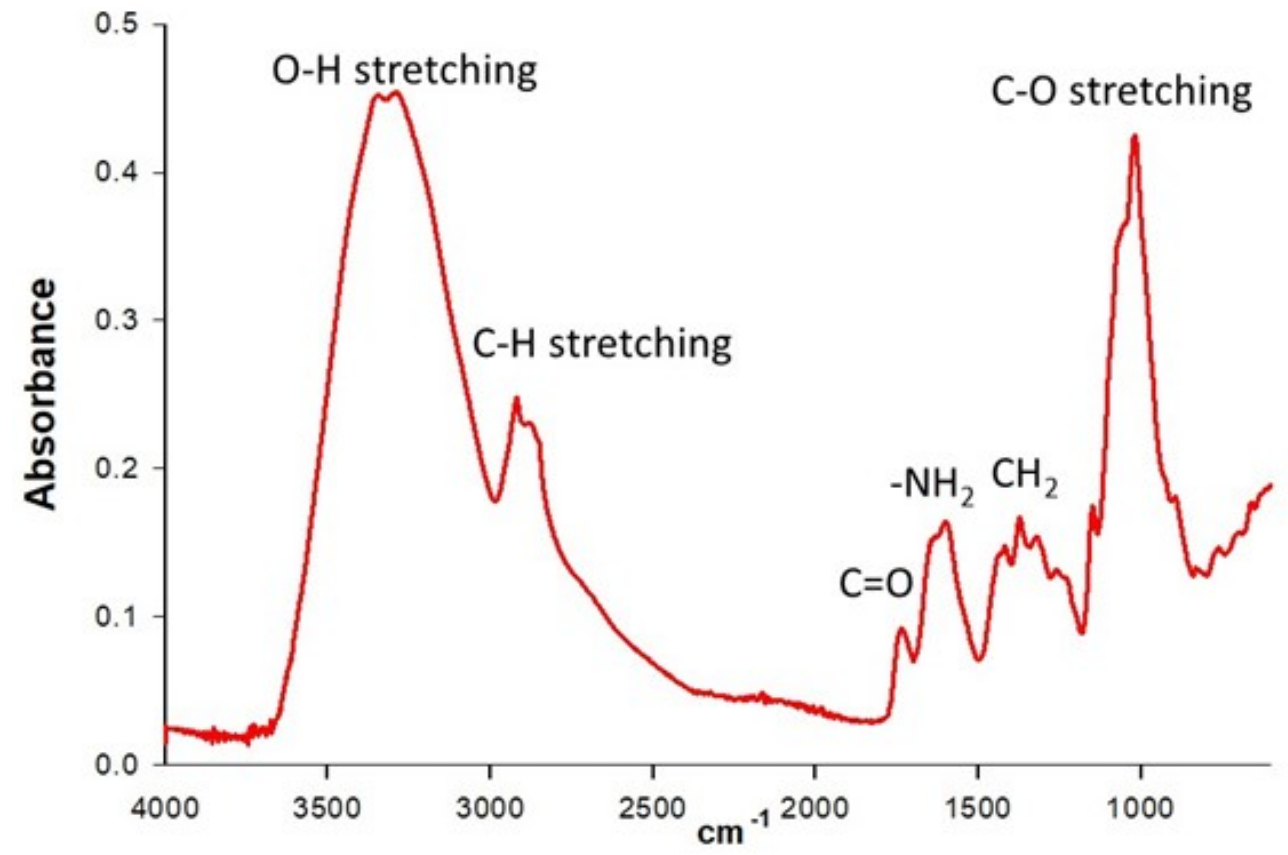

Figure 3. FT-IR spectrum corresponding to the chitosan sample.

Figures 4-7 show the radial growth kinetics of Colletotrichum isolates in medium PDA, PDA-lactic acid $(0.05 \mathrm{M})$, and PDA-lactic acid $(0.05 \mathrm{M})$ with $1 \mathrm{~g} \mathrm{~L}^{-1}$ of chitosan at $25^{\circ} \mathrm{C}$.

The isolate $\mathrm{H} 1-3$ was sensitive, but $\mathrm{C}$. fructicola isolates $\mathrm{H} 4-1$ and 003 were less sensitive to $1 \mathrm{~g} \mathrm{~L}^{-1}$ chitosan (Figure 4, Table 1). All the other Colletotrichum isolates were sensitive to chitosan (Table 1).

The C. fructicola isolate 003 was the only one obtained from the fruit. Its high growth on PDA-lactic acid contrasts with the growth on PDA because it may be adapted to develop in tissues with organic acids present (such as those present in the fruit). Lactic acid can sham the organic acids present in the fruit. The absence of these in the artificial PDA medium without the addition of lactic acid can be a factor that affects mycelial development. However, there are not enough data to hypothesize what happens with this isolate since it is the only one obtained from the fruit. 


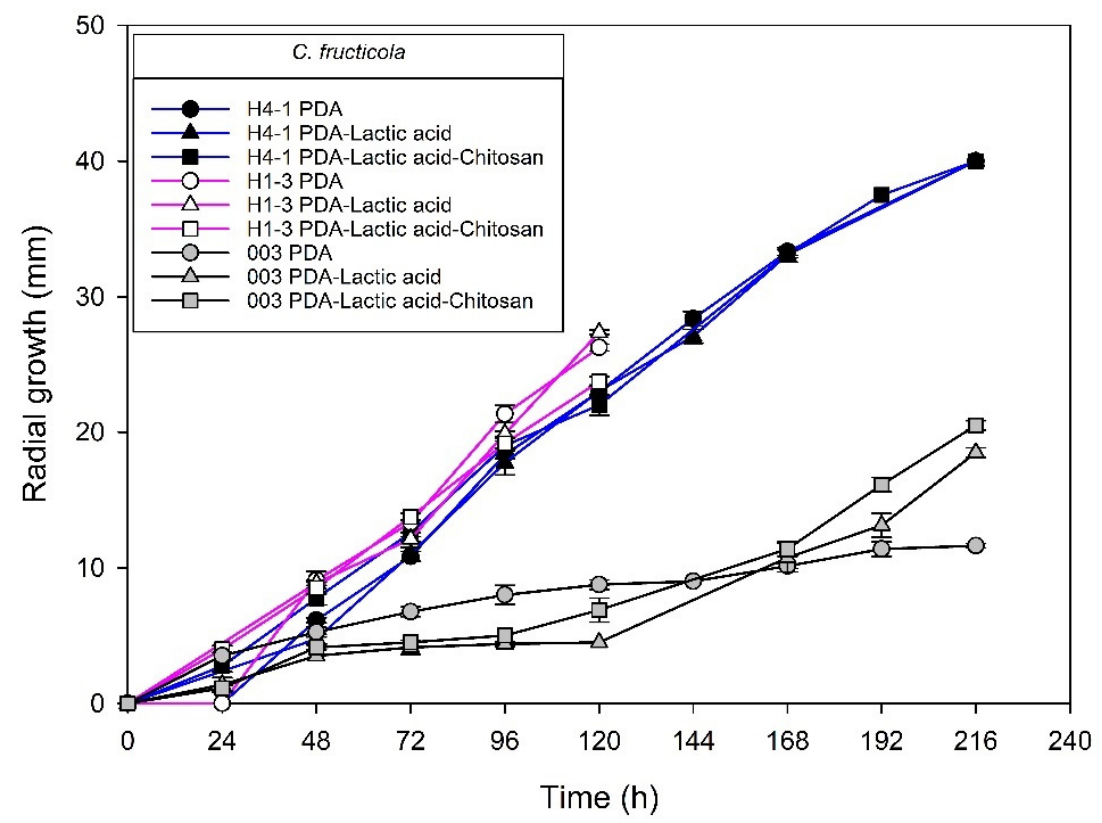

Figure 4. Colletotrichum fructicola species isolated from anthracnose of mango (H4-1, H1-3, and 003). Kinetics of radial growth $(\mathrm{mm})$ in medium PDA, PDA-lactic acid $(0.05 \mathrm{M})$, and PDA-lactic acid $(0.05 \mathrm{M})$ with $1 \mathrm{~g} \mathrm{~L}^{-1}$ chitosan at $25^{\circ} \mathrm{C}$.

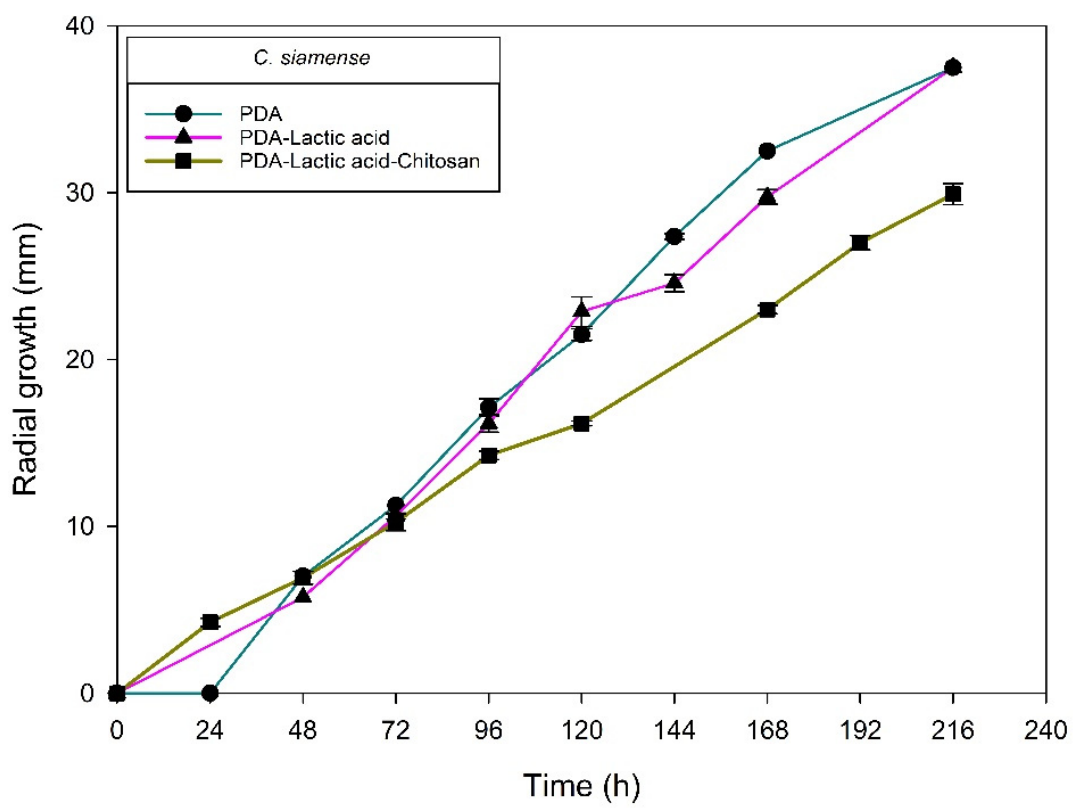

Figure 5. Colletotrichum siamense isolated (H6-1) from anthracnose of mango. Kinetics of radial growth $(\mathrm{mm})$ in medium PDA, PDA-lactic acid $(0.05 \mathrm{M})$, and PDA-lactic acid $(0.05 \mathrm{M})$ with $1 \mathrm{~g} \mathrm{~L}^{-1}$ chitosan at $25{ }^{\circ} \mathrm{C}$. 


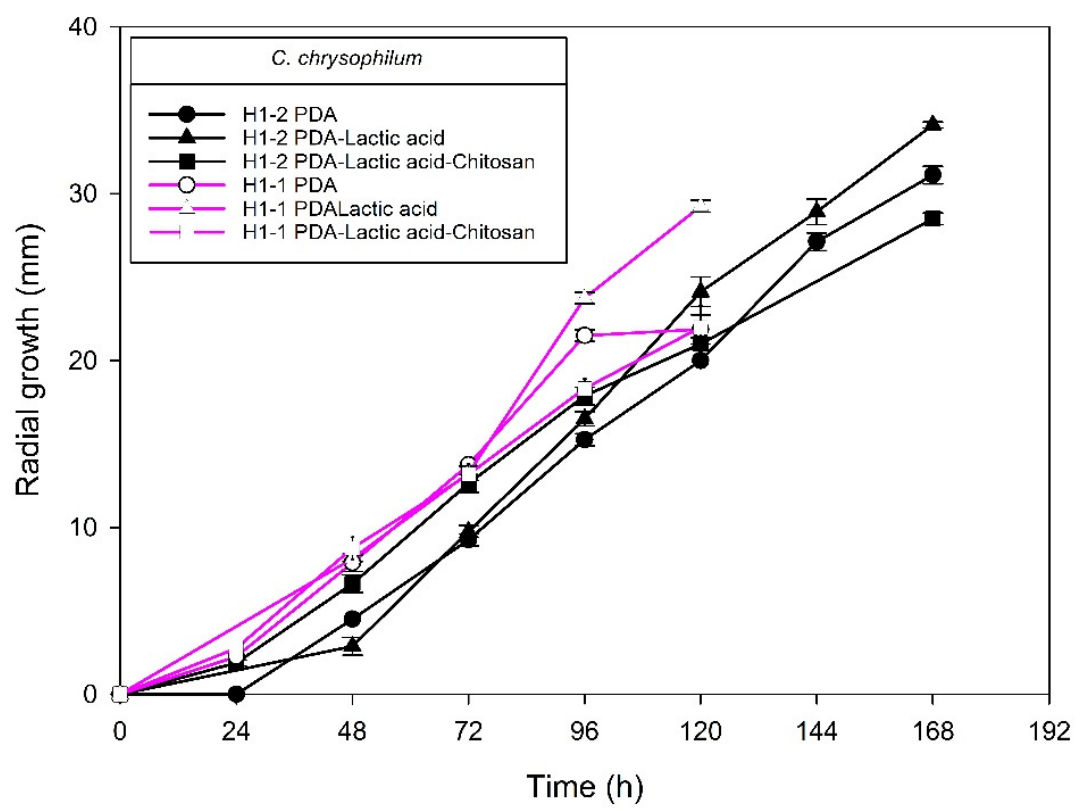

Figure 6. Colletotrichum chrysophilum isolates from anthracnose of mango (H1-2 and H1-1). Kinetics of radial growth $(\mathrm{mm})$ in medium PDA, PDA-lactic acid (0.05 M), and PDA-lactic acid (0.05 M) with $1 \mathrm{~g} \mathrm{~L}^{-1}$ chitosan at $25^{\circ} \mathrm{C}$.

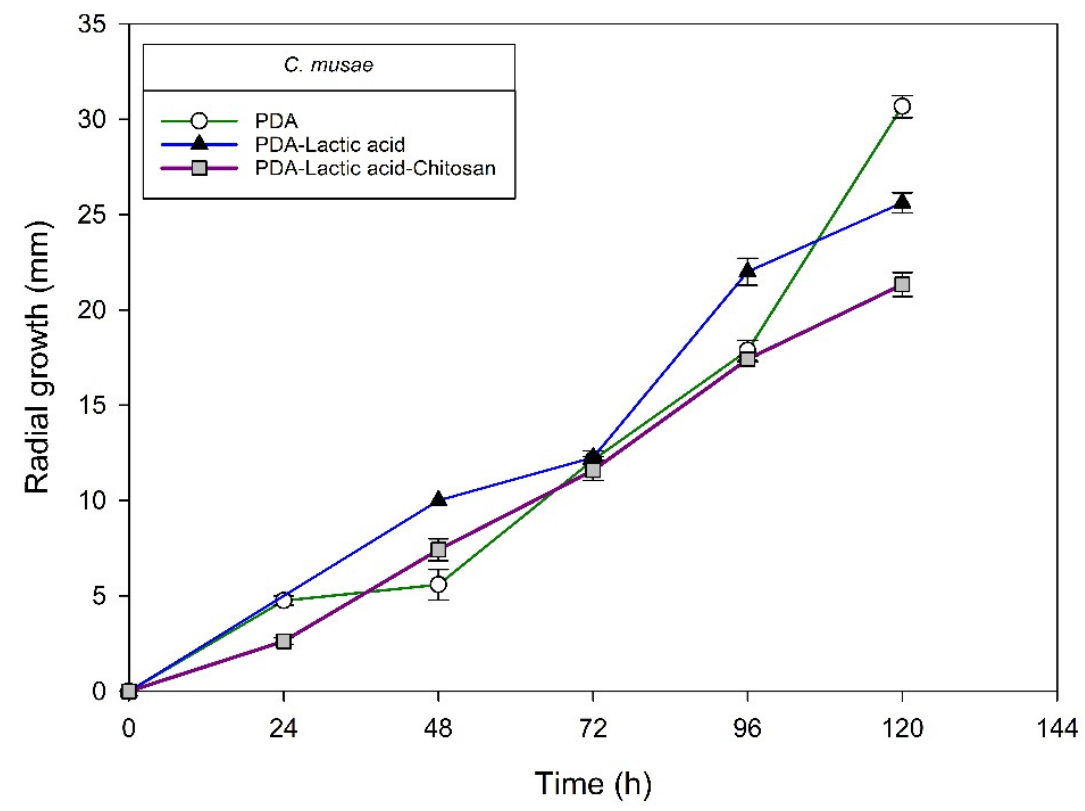

Figure 7. Colletotrichum musae isolated from anthracnose of mango. Kinetics of radial growth (mm) in medium PDA, PDA-lactic acid $(0.05 \mathrm{M})$, and PDA-lactic acid $(0.05 \mathrm{M})$ with $1 \mathrm{~g} \mathrm{~L}^{-1}$ chitosan at $25^{\circ} \mathrm{C}$.

Table 1 shows the radial growth rates in the log phase and the percentage of radial inhibition at $120 \mathrm{~h}$ of the Colletotrichum species causing anthracnose on mango from Mexico to chitosan at a concentration of $1 \mathrm{~g} \mathrm{~L}^{-1}$. Most isolates were susceptible to chitosan except for two C. fructicola specimens. 
Table 1. Chitosan against Colletotrichum gloeosporioides complex species isolated from anthracnose of mango. Rate of growth during log phase and growth radial inhibition in medium PDA, PDA-lactic acid $(0.05 \mathrm{M})$, and PDA-lactic acid $(0.05 \mathrm{M})$ with $1 \mathrm{~g} \mathrm{~L}^{-1}$ chitosan at $25^{\circ} \mathrm{C}$.

\begin{tabular}{|c|c|c|c|c|}
\hline \multirow{2}{*}{ Isolate/Species } & \multicolumn{3}{|c|}{$\begin{array}{l}\text { Rate of Growth in Log Phase } \\
\qquad \mathrm{m} \mathrm{h}^{-1}\end{array}$} & \multirow{2}{*}{$\begin{array}{c}\text { Inhibition of Radial } \\
\text { Growth }{ }^{1}(\%) \text { by } \\
\text { Chitosan at } 120 \mathrm{~h}\end{array}$} \\
\hline & PDA & PDA-Lactic Acid & $\begin{array}{l}\text { PDA-Lactic } \\
\text { Acid-Chitosan }\end{array}$ & \\
\hline H4-1/C. fructicola & $212 \pm 3^{\mathrm{CDa} 2}$ & $208 \pm 3^{\mathrm{Da}}$ & $202 \pm 4 \mathrm{ABa}$ & $2.84 \pm 2.30^{\mathrm{D}}$ \\
\hline H1-3/C. fructicola & $248 \pm 2^{\mathrm{Bb}}$ & $268 \pm 3^{\text {Ва }}$ & $217 \pm 2 \mathrm{Ac}$ & $13.38 \pm 1.28^{C}$ \\
\hline 003/C. fructicola & $30 \pm 4^{\mathrm{Fb} 2}$ & $117 \pm 5^{\mathrm{Fa}}$ & $126 \pm 0 \mathrm{Da}$ & $0.00 \pm 0.00^{\mathrm{D}}$ \\
\hline H6-1/C. siamense & $175 \pm 4$ Ea & $173 \pm 3^{\mathrm{Ea}}$ & $135 \pm 4^{\mathrm{CDb}}$ & $29.95 \pm 0.62^{\mathrm{A}}$ \\
\hline H1-2/C. chrysophilum & $228 \pm 0 \mathrm{Cb}$ & $242 \pm 0 \mathrm{Ca}$ & $149 \pm 2$ Cc & $12.95 \pm 1.46^{\mathrm{C}}$ \\
\hline H1-1/C. chrysophilum & $207 \pm 6^{\mathrm{Db}}$ & $307 \pm 1$ Аа & $187 \pm 7^{\mathrm{Bc}}$ & $22.43 \pm 1.20^{\mathrm{B}}$ \\
\hline H5-5/C. musae & $341 \pm 5^{\mathrm{Aa}}$ & $236 \pm 5^{\mathrm{Cb}}$ & $198 \pm 4^{\mathrm{Bc}}$ & $18.44 \pm 1.37^{\mathrm{B}}$ \\
\hline
\end{tabular}

PDA: potato dextrose agar. ${ }^{1}$ With respect to PDA-lactic acid $(0.05 \mathrm{M}) .{ }^{2}$ Means \pm standard deviation $(n=3)$ Values followed by different capital letters in columns and lowercase letters in rows are statistically different (Tukey $p \leq 0.05$ )

The effect of chitosan on fungal biological systems related to molecular weight (low, medium, or high) is well known. Low-molecular-weight chitosan can be more effective against mycelial growth [31]. Additionally, other studies have suggested that concentration may also be a factor that generates diverse defense responses in fungi. In general, over $1 \mathrm{~g} \mathrm{~L}^{-1}$ of chitosan inhibits $80-100 \%$ of the fungal growth [33,34], and it has complete in vitro inhibition from $10 \mathrm{~g} \mathrm{~L}^{-1}$ [35]. However, after several hours, growth recovers [36]. In contrast, low concentrations of chitosan ( $1 \mathrm{~g} \mathrm{~L}^{-1}$ and below) inhibit fungal growth [37-39], but there are other effects on the cell at low concentrations. Chitosan binds to the negatively charged cell surface, disturbs the cell membrane, inducing leakage of intracellular components [40], stimulates respiration, and produces the efflux of significant amounts of cations [36]. In Colletotrichum species, inhibitions of $25 \%$ to concentrations of $1 \mathrm{~g} \mathrm{~L}^{-1}$ have a fungistatic effect [41]. In this study, the antifungal capacity on mycelial growth was evaluated at concentrations of 0.1 to $1 \mathrm{~g} \mathrm{~L}^{-1}$ to cause a moderate attack of chitosan on fungal cells or fungistatic activity (not total inhibition or fungicide activity). Chitosan inhibited most of the isolates exposed to 0.75 and $1 \mathrm{~g} \mathrm{~L}^{-1}$ of chitosan (Table 2). The results of the other concentrations tested have been included in Table 2. The range of chitosan concentrations and inhibitions were insufficient to be able to estimate the MIC against isolated Colletotrichum. Adjusting final concentrations of chitosan at 10.0, 5.0, 2.5, 1.25, 0.625, 0.312 and $0.0 \mathrm{~g} \mathrm{~L}^{-1}$ can estimate the MIC for Colletotrichum gloeosporioides [42].

In the Colletotrichum isolates, the causal agent of anthracnose, it was possible to differentiate less susceptible strains of the same species at low concentrations (H4-1 and 003). This fact is relevant for future studies in our research group to elucidate the mechanisms of susceptibility or the possible resistance of Colletotrichum isolates to chitosan and should be studied based on genomic changes with molecular evidence.

The percentage of radial growth inhibition at a $1 \mathrm{~g} \mathrm{~L}^{-1}$ concentration of chitosan was greater than $10 \%$, and the radial growth rates of the log phase with respect to PDA-acid were reduced except for H4-1 and 003 isolates (Table 1). Earlier studies have shown the effect of chitosan on the radial growth of Colletotrichum species. Ramos et al. [43] reported radial growth inhibition at concentrations higher than $5 \mathrm{~g} \mathrm{~L}^{-1}$ chitosan with $40 \mathrm{kDa}$ molecular weight and $85 \%$ DD in C. asianum, C. fructicola, C. tropicale, and C. siamense species. 
Table 2. Radial growth inhibition of Colletotrichum gloeosporioides complex isolates and other genera isolates from mango (PDA-lactic acid-chitosan) at $25^{\circ} \mathrm{C}$.

\begin{tabular}{ccccc}
\hline Isolate/Species & \multicolumn{3}{c}{ Radial Growth Inhibition $\mathbf{~ ( \% ) ~ b y ~ C h i t o s a n ~} \mathbf{~ g ~ L ~}^{-\mathbf{1})}$ at 120 h } \\
\cline { 2 - 5 } & $\mathbf{0 . 1}$ & $\mathbf{0 . 5}$ & $\mathbf{0 . 7 5}$ & $\mathbf{1}$ \\
\hline H4-1/C. fructicola & $13.85 \pm 0.93^{2}$ & $12.27 \pm 1.08$ & $0.00 \pm 0.00$ & $2.84 \pm 2.30$ \\
H1-3/C. fructicola & $0.00 \pm 0.00$ & $10.09 \pm 0.70$ & $12.84 \pm 1.29$ & $13.38 \pm 1.28$ \\
003/C. fructicola & $0.00 \pm 0.00$ & $0.00 \pm 0.00$ & $0.00 \pm 0.00$ & $0.00 \pm 0.00$ \\
H6-1/C. siamense & $6.00 \pm 0.54$ & $12.56 \pm 0.28$ & $23.44 \pm 2.95$ & $29.95 \pm 0.62$ \\
H1-2/C. chrysophilum & $40.89 \pm 2.16$ & $26.40 \pm 1.23$ & $42.99 \pm 0.62$ & $12.95 \pm 1.46$ \\
H1-1/C. chrysophilum & $0.00 \pm 0.00$ & $20.08 \pm 0.36$ & $19.22 \pm 0.371$ & $22.43 \pm 1.20$ \\
H5-5/C.musae & $0.00 \pm 0.00$ & $13.16 \pm 0.41$ & $11.69 \pm 1.13$ & $18.44 \pm 1.37$ \\
004/Alternaria sp. & $0.00 \pm 0.00$ & $18.67 \pm 2.84$ & $19.31 \pm 0.97$ & $20.28 \pm 2.40$ \\
009-1/Alternaria sp. & $0.00 \pm 0.00$ & $37.08 \pm 1.94$ & $33.37 \pm 1.74$ & $24.07 \pm 2.62$ \\
H6-1b/Alternaria tenuissima & $0.00 \pm 0.00$ & $68.83 \pm 0.00$ & $68.18 \pm 2.75$ & $72.72 \pm 1.84$ \\
H2-2/Fusarium sp. & $0.00 \pm 0.00$ & $53.46 \pm 0.54$ & $39.61 \pm 0.54$ & $71.54 \pm 0.00$ \\
H2-3/Fusarium sp. & $38.39 \pm 0.92$ & $77.25 \pm 0.15$ & $81.51 \pm 0.54$ & $87.62 \pm 0.00$ \\
H2-7/Pestalotiopsis sp. & $0.00 \pm 0.00$ & $54.68 \pm 0.44$ & $67.81 \pm 1.32$ & $67.18 \pm 0.44$ \\
H2-9/Pestalotiopsis sp. & $0.00 \pm 0.00$ & $62.23 \pm 2.54$ & $59.71 \pm 2.03$ & $74.87 \pm 0.00$ \\
H5-3/Pestalotiopsis sp. & $16.28 \pm 0.53$ & $49.63 \pm 0.62$ & $54.49 \pm 0.07$ & $43.33 \pm 1.57$ \\
H3-8/Curvularia lunata & $0.00 \pm 0.00$ & $50.53 \pm 0.75$ & $59.33 \pm 0.34$ & $65.22 \pm 1.88$ \\
008/Diaporthe pseudomangiferae & $0.00 \pm 0.00$ & $45.66 \pm 0.30$ & $60.72 \pm 2.30$ & $53.75 \pm 0.0$ \\
H6-2/Epicoccum nigrum & $10.26 \pm 0.37$ & $44.42 \pm 0.80$ & $59.82 \pm 0.24$ & $69.22 \pm 1.71$ \\
\hline
\end{tabular}

PDA: potato dextrose agar. ${ }^{1}$ With respect PDA-lactic acid $(0.05 \mathrm{M}) .{ }^{2}$ Means \pm standard deviation $(n=3)$.

Radial extension rate decreased in most of the Colletotrichum species growing in vitro with chitosan. The growth of fungi includes four distinctive phases: the lag phase (I), the log phase (II), the slow down phase (III), and the steady growth phase (IV) [44]. During the log phase of balanced growth, the mycelium of fungi undergoes primary metabolism [45], so a decrease in rate is indicative of fungistatic activity by inhibition of the primary metabolism. However, radial growth of the C. fructicola isolate H4-1 from leaves was less inhibited, while 003 from the fruit was not inhibited with $1 \mathrm{~g} \mathrm{~L}^{-1}$ chitosan at $120 \mathrm{~h}$; their log phase radial extension rates were not affected by the low molecular weight chitosan. No earlier studies were found in which the effect of chitosan was evaluated on C. fructicola isolates identified to the species level using more than three genetic markers, which is necessary to ensure proper identification to the species level in the genus Colletotrichum. Ramos et al. [43] reported inhibition of $C$. fructicola at a $5 \mathrm{~g} \mathrm{~L}^{-1}$ chitosan concentration; however, this species was one of the less inhibited by chitosan, although it showed hyphae with granular and corrugated surface when exposed to chitosan. The lower inhibition that chitosan exerted on isolates H4-1 and 003 may also be related to the virulence of the fungus; for instance, $C$. fructicola was more aggressive than $C$. siamense on peach [46], but in mango from Mexico, it has been reported that $C$. siamense and $C$. asianum have higher virulence than C. fructicola [22]. These variations in the degree of virulence of the fungus with its host can also be reflected in the sensitivity to fungicides that are applied, so one of the aspects to consider for the control of Colletotrichum complex species is the execution of fungicide sensitivity test [21] with a species-level identification using more than three genetic markers. In our study, two strains of $C$. fructicola were less susceptible. Therefore, it would be interesting to evaluate if there is a relationship between the degree of virulence (high or low) in mango and the sensitivity to chitosan as a hypothesis to be tested in future studies.

Concerning the fungi that did not belong to the Colletotrichum genus, all the isolates found were susceptible to chitosan (Table 3; Figures 8-13 and Table 2). In Mexico, anthracnose is the primary disease caused by Colletotrichum that affects mango crops, but it is not discarded that the infections caused by other fungal genera can generate problems for mango production; in that case, chitosan may be an alternative to evaluate. Furthermore, 
the presence of these fungi could affect the fruit quality by worsening necrotic signs at sites initially injured by Colletotrichum.

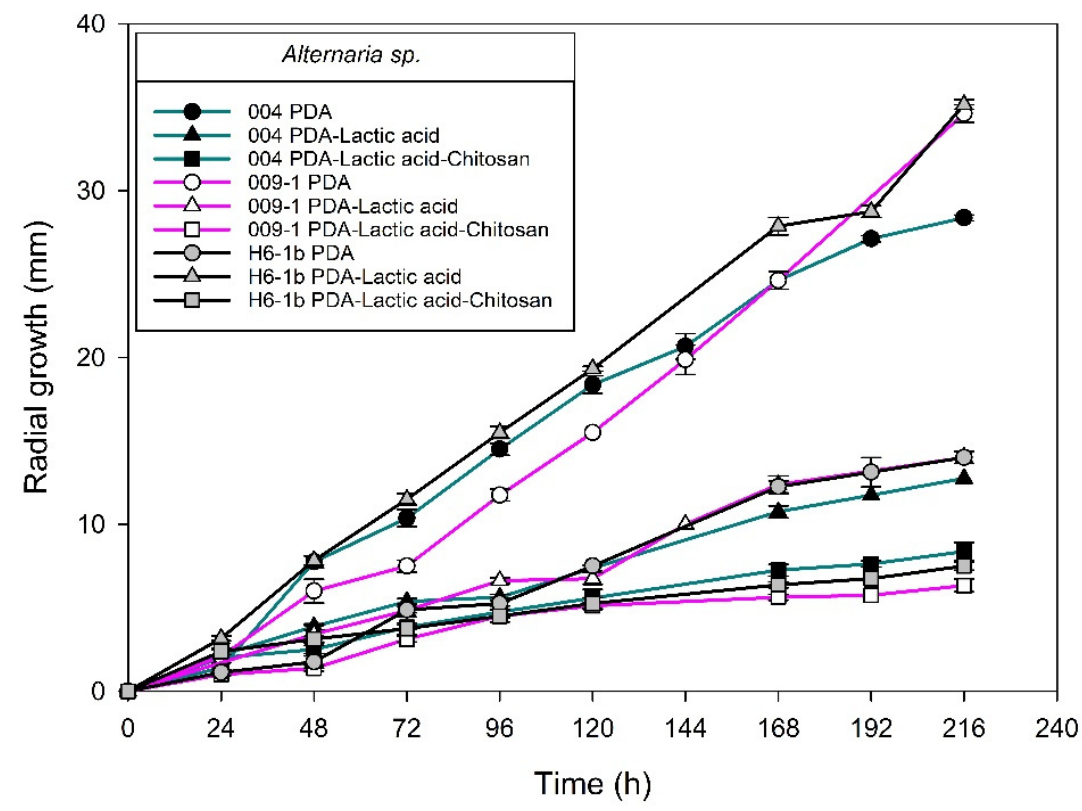

Figure 8. Alternaria sp. isolated from anthracnose of mango. Kinetics of radial growth (mm) in medium PDA, PDA-lactic acid $(0.05 \mathrm{M})$, and PDA-lactic acid $(0.05 \mathrm{M})$ with $1 \mathrm{~g} \mathrm{~L}^{-1}$ chitosan at $25^{\circ} \mathrm{C}$.

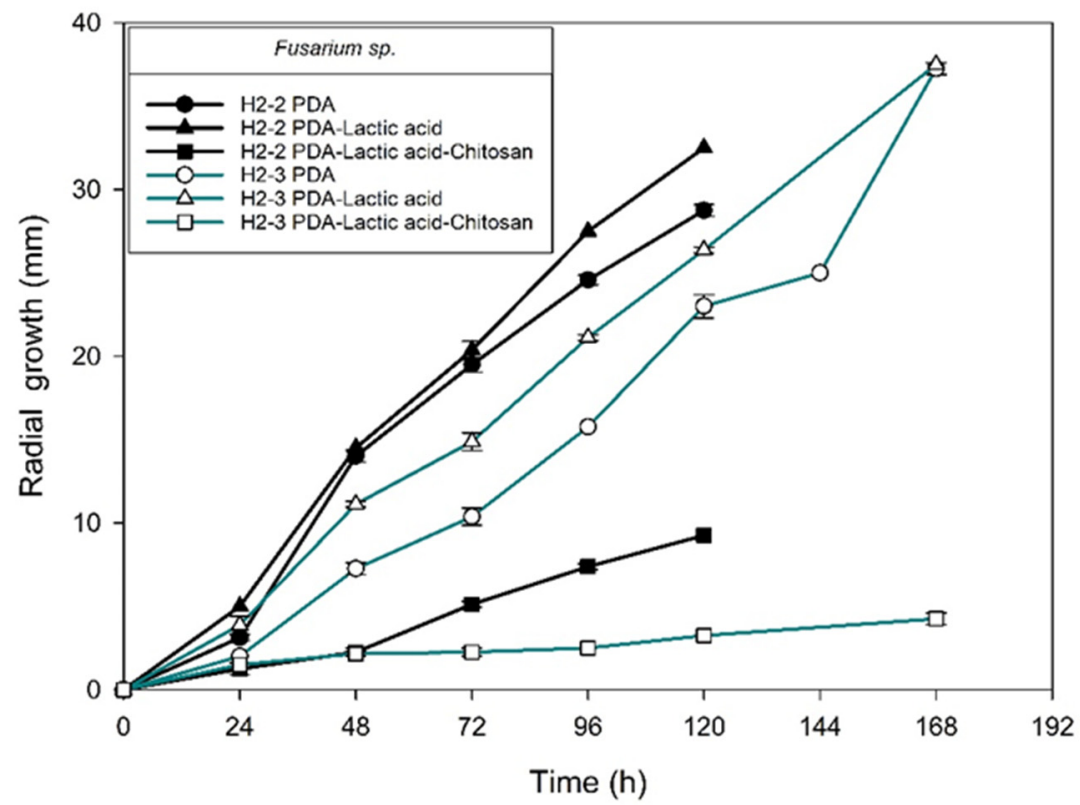

Figure 9. Fusarium sp. isolates from anthracnose of mango. Kinetics of radial growth $(\mathrm{mm})$ in medium PDA, PDA-lactic acid $(0.05 \mathrm{M})$, and PDA-lactic acid $(0.05 \mathrm{M})$ with $1 \mathrm{~g} \mathrm{~L}^{-1}$ chitosan at $25^{\circ} \mathrm{C}$. 


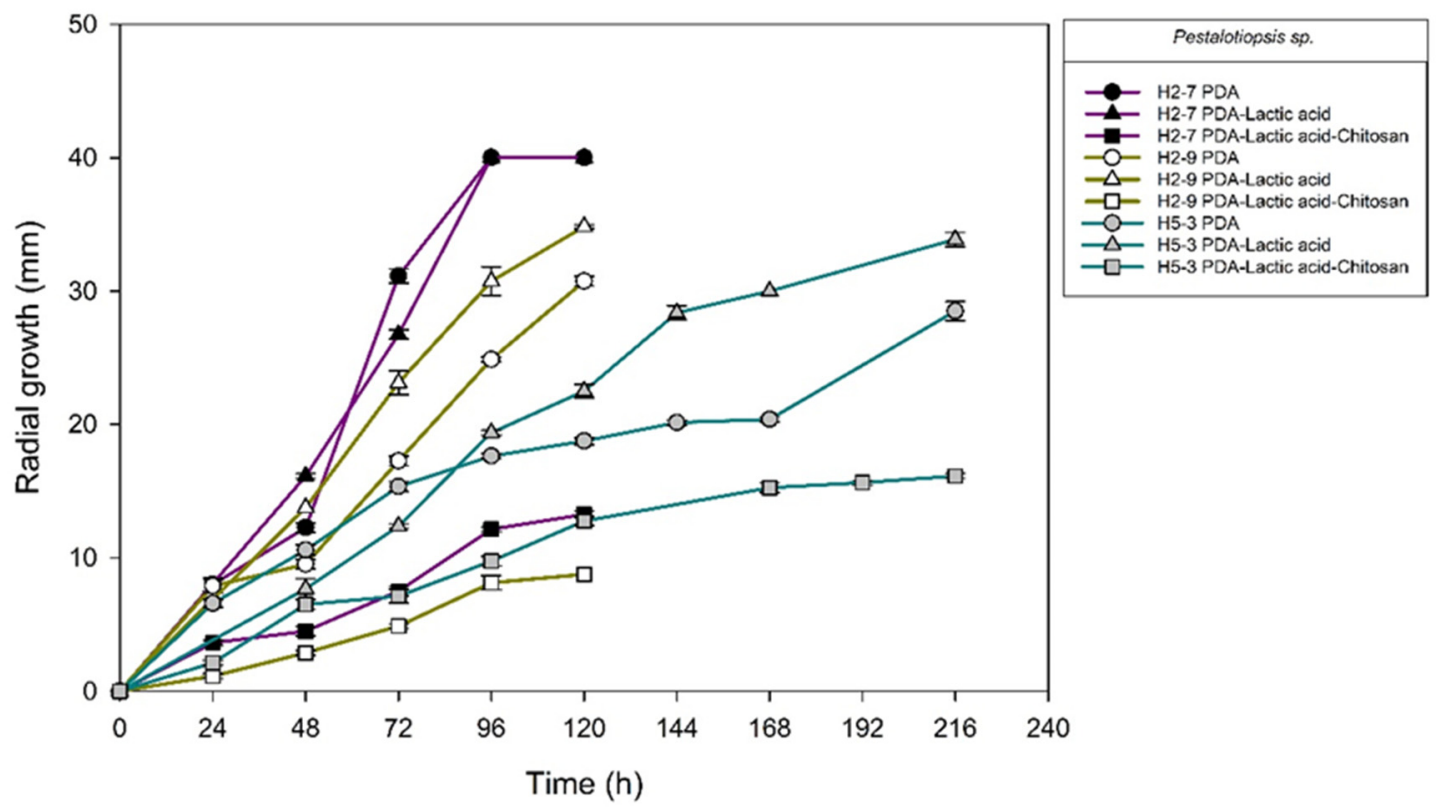

Figure 10. Pestalotiopsis sp. isolates from anthracnose of mango. Kinetics of radial growth $(\mathrm{mm})$ in medium PDA, PDA-lactic acid $(0.05 \mathrm{M})$, and PDA-lactic acid $(0.05 \mathrm{M})$ with $1 \mathrm{~g} \mathrm{~L}^{-1}$ chitosan at $25^{\circ} \mathrm{C}$.

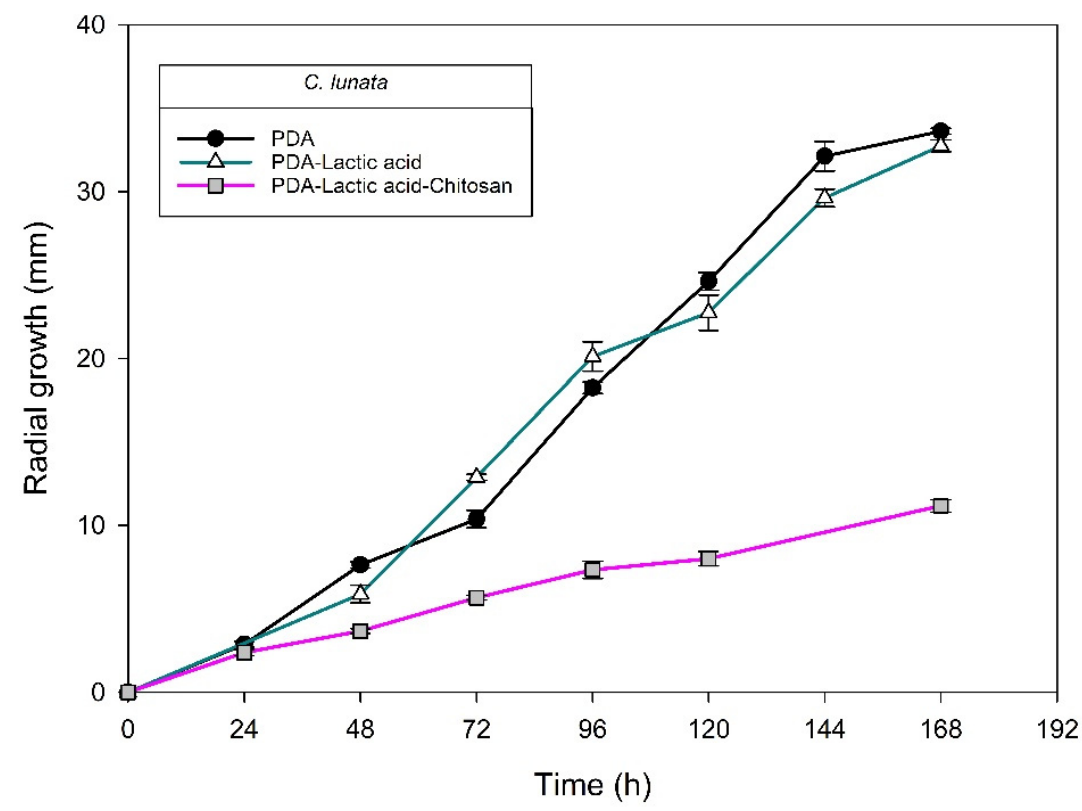

Figure 11. Curvularia lunata isolated from anthracnose of mango. Kinetics of radial growth (mm) in medium PDA, PDA-lactic acid $(0.05 \mathrm{M})$, and PDA-lactic acid $(0.05 \mathrm{M})$ with $1 \mathrm{~g} \mathrm{~L}^{-1}$ chitosan at $25^{\circ} \mathrm{C}$. 


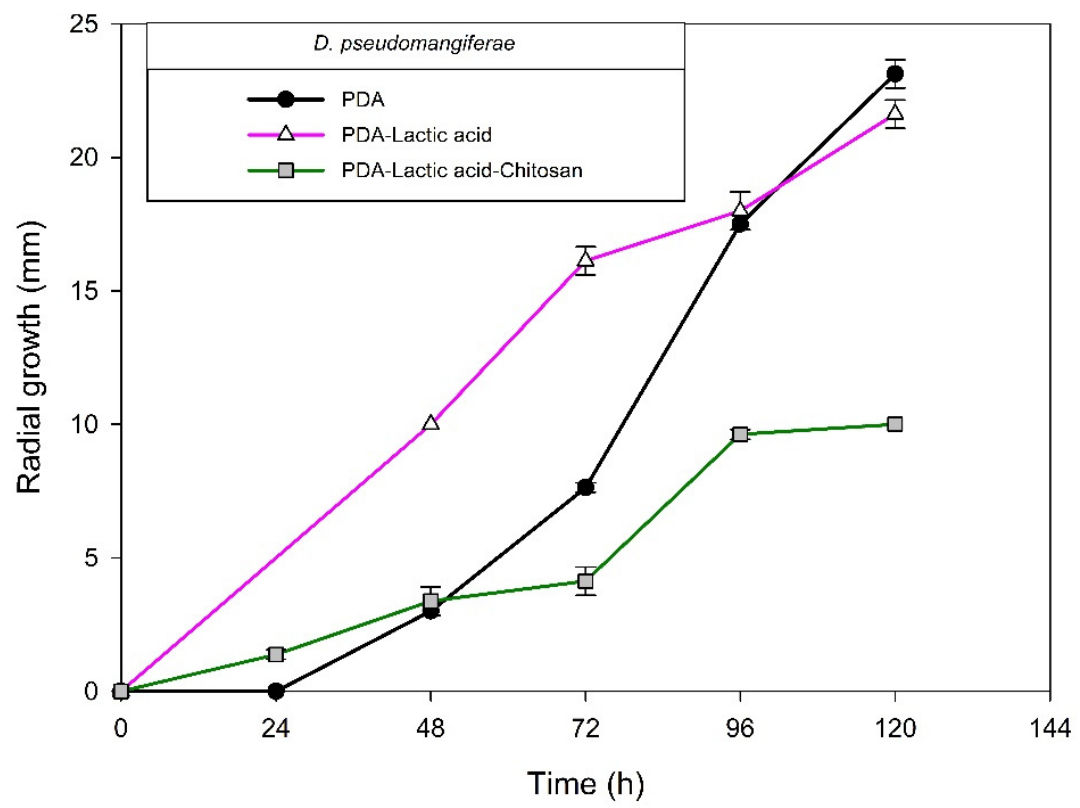

Figure 12. Diaporthe pseudomangiferae isolated from anthracnose of mango. Kinetics of radial growth $(\mathrm{mm})$ in medium PDA, PDA-lactic acid $(0.05 \mathrm{M})$, and PDA-lactic acid $(0.05 \mathrm{M})$ with $1 \mathrm{~g} \mathrm{~L}^{-1}$ chitosan at $25^{\circ} \mathrm{C}$.

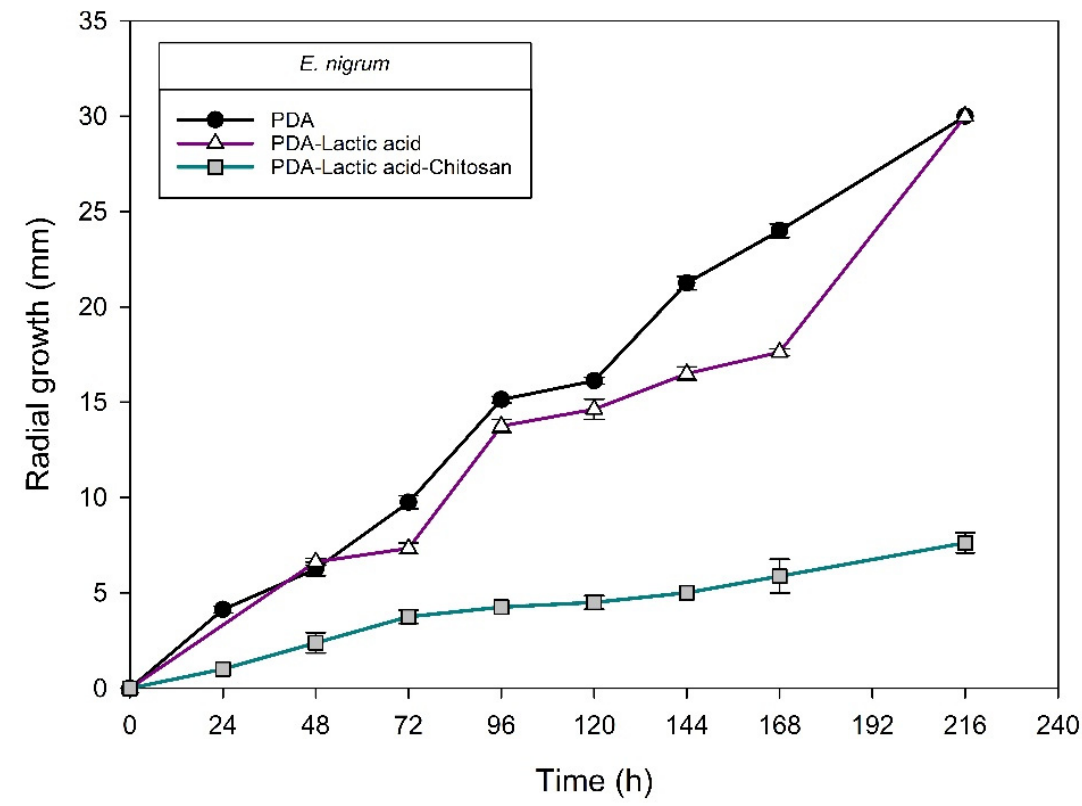

Figure 13. Epicoccum nigrum isolated from anthracnose of mango. Kinetics of radial growth (mm) in medium PDA, PDA-lactic acid $(0.05 \mathrm{M})$, and PDA-lactic acid $(0.05 \mathrm{M})$ with $1 \mathrm{~g} \mathrm{~L}^{-1}$ chitosan at $25^{\circ} \mathrm{C}$.

Fungal isolates of plant tissue with anthracnose in mango from Mexico belong to the Colletotrichum complex. The use of seven genetic markers in the genomic alignment identified the species C. fructicola, C. musae, and C. chrysophilum. The fungi of the Colletotrichum complex are susceptible to chitosan except for two isolates of the species $C$. fructicola that showed less susceptibility to chitosan. Likewise, the genera Alternaria, Fusarium, Pestalotiopsis, Curvularia, Diaporthe, and Epicoccum, which cause other diseases in mango, showed susceptibility to chitosan in all cases. Therefore, chitosan is an alternative to be evaluated in the control of anthracnose and other fungal infections in mango. However, due to the demonstrated lower susceptibility to chitosan presented by a C. fructicola specimen, the 
interactions between the species of the complex of C. gloeosporioides in anthracnose and their effect on the susceptibility or resistance to chitosan must be considered.

Table 3. Chitosan sensitivity of other fungi species isolated from anthracnose on mango. Radial growth in medium PDA, PDA-lactic acid (0.05 M), and PDA-lactic acid (0.05 M) with $1 \mathrm{~g} \mathrm{~L}^{-1}$ chitosan at $25^{\circ} \mathrm{C}$.

\begin{tabular}{|c|c|c|c|c|}
\hline \multirow[t]{2}{*}{ Isolate/Specie } & \multicolumn{3}{|c|}{$\begin{array}{l}\text { Radial Growth Rate: Log Phase } \\
\qquad\left(\mu \mathrm{m} \mathrm{h}^{-1}\right)\end{array}$} & \multirow{2}{*}{$\begin{array}{c}\text { Inhibition }^{1} \text { of Radial } \\
\text { Growth (\%) by } \\
\text { Chitosan at } 120 \mathrm{~h}\end{array}$} \\
\hline & PDA & PDA-Lactic Acid & PDA-Lactic Acid Chitosan & \\
\hline 004/Alternaria sp. & $116 \pm 2^{\mathrm{a} 2}$ & $60 \pm 1^{b}$ & $35 \pm 1^{c}$ & $20.28 \pm 2.40^{\mathrm{G}}$ \\
\hline 009-1/Alternaria sp. & $192 \pm 3^{b}$ & $294 \pm 3^{a}$ & $17 \pm 4^{\mathrm{c}}$ & $24.07 \pm 2.62^{G}$ \\
\hline H6-1b/Alternaria tenuissima & $76 \pm 3^{b}$ & $155 \pm 3^{a}$ & $24 \pm 3^{c}$ & $72.72 \pm 1.84^{\mathrm{BC}}$ \\
\hline $\mathrm{H} 2-2 /$ Fusarium sp. & $206 \pm 1^{b}$ & $255 \pm 2^{a}$ & $105 \pm 7^{c}$ & $71.54 \pm 0.00^{\mathrm{BC}}$ \\
\hline $\mathrm{H} 2-3 /$ Fusarium sp. & $277 \pm 1^{\mathrm{a}}$ & $228 \pm 3^{b}$ & $23 \pm 4^{c}$ & $87.62 \pm 0.00^{\mathrm{A}}$ \\
\hline $\mathrm{H} 2-7 /$ Pestalotiopsis sp. & $578 \pm 7^{\mathrm{a}}$ & $497 \pm 4^{b}$ & $159 \pm 4^{\mathrm{c}}$ & $67.18 \pm 0.44^{C D}$ \\
\hline H2-9/Pestalotiopsis sp. & $297 \pm 1^{a}$ & $294 \pm 1 \mathrm{~b}$ & $87 \pm 1^{\mathrm{c}}$ & $74.87 \pm 0.00^{\mathrm{B}}$ \\
\hline H5-3/Pestalotiopsis sp. & $40 \pm 0^{\mathrm{c}}$ & $158 \pm 1^{\mathrm{a}}$ & $59 \pm 1^{b}$ & $43.33 \pm 1.57^{\mathrm{F}}$ \\
\hline H3-8/Curvularia lunata & $223 \pm 1^{a}$ & $186 \pm 8^{b}$ & $55 \pm 1^{\mathrm{c}}$ & $65.22 \pm 1.88^{\mathrm{D}}$ \\
\hline 008/Diaporthe pseudomangiferae & $293 \pm 6^{a}$ & $153 \pm 7^{b}$ & $106 \pm 8^{c}$ & $53.75 \pm 0.0^{\mathrm{E}}$ \\
\hline H6-2/Epicoccum nigrum & $133 \pm 2^{a}$ & $56 \pm 3^{b}$ & $12 \pm 1^{\mathrm{c}}$ & $69.22 \pm 1.71^{\mathrm{BCD}}$ \\
\hline
\end{tabular}

PDA: potato dextrose agar. ${ }^{1}$ With respect to PDA-lactic acid $(0.05 \mathrm{M}) .{ }^{2}$ Means \pm standard deviation $(n=3)$ Values followed by different capital letters in columns and lowercase letters in rows are statistically different (Tukey $p \leq 0.05$ ).

\section{Materials and Methods}

\subsection{Identification of Fungal Isolates}

Colletotrichum isolates were obtained in the 2019 agricultural cycle from Cuajinicuilapa, Guerrero, Mexico. Mango leaves with anthracnose symptoms from the lower foliage of the tree were cut from the petiole and stored individually on paper towels. A leaf with anthracnose disease contains black necrotic spots of irregular shape on both sides of the leaf. The infected leaves were transferred to the laboratory at room temperature to obtain fungal isolates. Likewise, samplings were carried out on commercial maturity mango fruit with anthracnose from Guerrero. A mango with anthracnose shows deep, prominent, and generally rounded dark brown to black spots [20,47]. From the infected leaves and fruits, $0.5 \times 0.5 \mathrm{~cm}$ tissue sections cuts were obtained and disinfected with sodium hypochlorite $(\mathrm{NaOCl}) 0.5 \%(v / v)$ for $2 \mathrm{~min}$; then they were washed with sterile distilled water and dried with sterile filter paper. Each fragment was individually deposited in the center of a Petri dish with culture medium Potato Dextrose Agar (PDA) and incubated at $25{ }^{\circ} \mathrm{C}$ in the absence of light until the progress of mycelium for 8-10 days.

DNA extraction was carried out from mycelium of each colony, a sterile scalpel was used to obtain $100 \mathrm{mg}$ of mycelium, and it was placed in Eppendorf tubes (5 Ml). The mycelium breaking was carried out through three methods; in the first method, the mycelium sample was crushed by liquid nitrogen using a mortar; in the second, glass beads and vortex were used, crushing the mycelium for $1 \mathrm{~min}$, and the third method was using a grinder with pellet pestles. The third method resulted in better DNA extraction yields. The fungal isolates were identified by a multi-locus sequence analysis scheme based on five genes (actin, Act; beta-tubulin 2, $\beta$-Tub 2 ; glyceraldehyde-3-phosphate dehydrogenase, GAPDH; chitin synthase 1, CHS-1; calmodulin, CaM) and the ribosomal internal transcribed spacer (ITS) and Apn2-Mat1-2 (ApMat) intergenic spacer regions. Genomic DNA was extracted with the Plant/Fungi DNA Isolation Kit (Norgen Biotek Corporation, Canada) following the manufacturer's instructions and used as a template for PCR reactions using the GoTaq ${ }^{\circledR}$ Flexi DNA Polymerase (Promega, USA) and specific primers for each gene (Table 4). 
Table 4. Primer sequences for identification of fungal isolates.

\begin{tabular}{|c|c|c|c|}
\hline Genetic Marker & Forward $\left(5^{\prime}-3^{\prime}\right)$ & Reverse $\left(5^{\prime}-3^{\prime}\right)$ & Reference \\
\hline Internal transcribed spacers (ITS) & $\begin{array}{c}\text { ITS1 } \\
\text { (TCCGTAGGTGAACCTGCGG) }\end{array}$ & $\begin{array}{c}\text { ITS4 } \\
\text { (TCCTCCGCTTATTGATATGC) }\end{array}$ & {$[48,49]$} \\
\hline $\begin{array}{c}\beta \text {-tubulin } 2 \\
\left(\beta-\mathrm{Tub}_{2}\right)\end{array}$ & $\begin{array}{c}\text { Bt2a } \\
\text { (GGTAACCAAATCGGTGCTGCTTTC) }\end{array}$ & $\begin{array}{c}\text { Bt2b } \\
\text { (ACCCTCAGTGTAGTGACCCTTGGC) }\end{array}$ & [48] \\
\hline $\begin{array}{l}\text { Glyceraldehyde-3-phosphate } \\
\text { dehydrogenase } \\
\text { (GAPDH) }\end{array}$ & $\begin{array}{c}\text { GDF1 } \\
\text { (GCCGTCAACGACCCCTTCATTGA) }\end{array}$ & $\begin{array}{c}\text { GDR1 } \\
\text { (GGGTGGAGTCGTACTTGAGCATGT) }\end{array}$ & [48] \\
\hline $\begin{array}{l}\text { Actin } \\
\text { (Act) }\end{array}$ & $\begin{array}{c}\text { ACT-512F } \\
\text { (ATGTGCAAGGCCGGTTTCGC) }\end{array}$ & $\begin{array}{c}\text { ACT-783R } \\
\text { (TACGAGTCCTTCTGGCCCAT) }\end{array}$ & {$[48,49]$} \\
\hline $\begin{array}{l}\text { Calmodulin } \\
\quad(\text { CaM })\end{array}$ & $\begin{array}{c}\text { CL1C } \\
\text { (GAATTCAAGGAGGCCTTCTC) }\end{array}$ & $\begin{array}{c}\text { CL2C } \\
\text { (CTTCTGCATCATGAGCT GAC) }\end{array}$ & [48] \\
\hline $\begin{array}{c}\text { Chitin synthase } \\
\text { (CHS-1) }\end{array}$ & $\begin{array}{l}\text { CHS1-79F (TGGGGCAAGGATGCTTG- } \\
\text { GAAGAAG) }\end{array}$ & $\begin{array}{c}\text { CHS-1-354R } \\
\text { (TGGAAGAACCATCTGTGAGAGTTG) }\end{array}$ & {$[48,49]$} \\
\hline $\begin{array}{c}\text { Apn2-Mat1-2 intergenic spacer } \\
\text { (ApMat) }\end{array}$ & $\begin{array}{c}\text { AMF1 } \\
\text { (TCATTCTACGTATGTGCCCG) }\end{array}$ & $\begin{array}{c}\text { AMR1 } \\
\text { (CCAGAAATACACCGAACTTGC) }\end{array}$ & {$[50]$} \\
\hline
\end{tabular}

The PCR products were purified with GFX columns (Amersham Bio-sciences, Piscataway, NJ, USA) and sequenced at Macrogen Inc. (Seoul, Korea). Sequences were analyzed against the GenBank database with the Blast tool (https:/ /blast.ncbi.nlm.nih.gov/Blast.cgi), and the DNA sequences of the top hit matches were used as reference organisms for phylogenetic analysis. DNA sequence alignments were performed with the Clustal W function. Two concatenated phylogenetic trees were constructed with MEGA-X software v. 10.2.6. using the maximum-likelihood method and the general time-reversible model with gamma distribution and proportion of invariable sites $(G T R+G+I)$ to estimate the evolutionary distances (1000 bootstrap replicates) [49,51]. For the first one, the combined sequences of ITS and $\beta-\mathrm{Tub}_{2}$ were used to determine the genus of the fungal isolates. In contrast, the second tree was constructed using ITS, Act, $\beta$-Tub 2 , GAPDH, CHS- 1 , CaM, and ApMat sequences that were directed to characterize the members of the Colletotrichum complexes, which are associated with anthracnosis disease in Mangifera indica L.

\subsection{Chitosan Characterization and Sensitivity of Isolated Fungi}

Low-molecular-weight chitosan (Aldrich, lot \# STBF3282V, Saint Louis, MO, USA) was mixed and triturated with $120 \mathrm{mg}$ of $\mathrm{KBr}$ for $10 \mathrm{~min}$. The mixture was compacted with a hydraulic press ( 8 tons of pressure for $16 \mathrm{~h}$ ), and the formed tablet was analyzed using a Fourier transformed infrared (FT-IR) resonance spectrometer (Spectrum GX FT-IR System, Perkin Elmer ${ }^{\mathrm{TM}}$, Shelton, CT, USA). The spectrum obtained was within the frequency range of $4000-400 \mathrm{~cm}^{-1}$ [52]. The DD was calculated by the method proposed by Brugnerotto et al. [53] using reference baselines in the FT-IR spectrum to 1320 and $1420 \mathrm{~cm}^{-1}$ with equations 1 and 2 of Table 4.

The molecular weight $(\mathrm{kDa})$ was obtained using Mark-Houwink-Sakurada (Table 5) where $[\eta]$ is the intrinsic viscosity of the polymer, Mv average molecular weight in $\mathrm{Da}$ $\left(\mathrm{g} \mathrm{mol}^{-1}\right), \mathrm{k}=0.070 \mathrm{~g} \mathrm{ml}^{-1}$, and $\alpha=0.81$ according to the DD of chitosan $[54,55]$. The intrinsic viscosity was calculated by extrapolating to zero concentration of the Huggins, and Kraemer equations (Table 4) [56,57], using an Ubbelohde viscosimeter (0B-L123, CANNON) submerged in a water bath recirculation system at a constant temperature of $25^{\circ} \mathrm{C}$. Chitosan solutions were prepared with concentrations of $0.003-0.002 \mathrm{~g} \mathrm{~L}^{-1}$ [54], using a solution of $0.3 \mathrm{M}$ acetic acid and $0.2 \mathrm{M}$ sodium acetate as a solvent [58]. 
Table 5. Equations for determining the deacetylation degree and molecular weight of chitosan.

\begin{tabular}{cc}
\hline Number or Name of Equation & Equation \\
\hline 1 (DA: acetylation degree) & $\frac{A_{1320}=0.3822+0.03133 D A}{A_{1420}}=D D=100-D A$ \\
2 (DD: deacetylation degree) & $\eta_{\text {rel }}=\mathrm{t}_{\text {flux solution of chitosan }} / \mathrm{t}_{\text {flux of solvent }}$ \\
Relative viscosity & $\eta_{\mathrm{sp}}=\eta_{\text {rel }}-1$ \\
Specific viscosity & {$[\eta]=\eta_{\mathrm{sp}} / \mathrm{C}$} \\
Huggins & {$[\eta]=\left(\ln \eta_{\mathrm{rel}}\right) / \mathrm{C}$} \\
Kramer & {$[\eta]=\mathrm{k}(\mathrm{Mv})^{\alpha}$} \\
Mark-Houwink-Sakurada &
\end{tabular}

The chitosan activity in mycelial growth was evaluated over the fungal isolates obtained. A chitosan solution in lactic acid $(0.05 \mathrm{M})$ was prepared; the $\mathrm{pH}$ was adjusted with $\mathrm{NaOH}(1 \mathrm{~N})$ to 5.6 and sterilized for $15 \mathrm{~min}$ at $121^{\circ} \mathrm{C}$. Likewise, a culture medium with potato dextrose agar (PDA) was prepared and sterilized. At $45^{\circ} \mathrm{C}$, the chitosan solution and the PDA culture medium were mixed, and $20 \mathrm{~mL}$ were poured into sterile Petri dishes and cooled until solidified. The treatments obtained were PDA culture medium, acidified PDA culture medium ( $0.05 \mathrm{M}$ lactic acid), and acidified PDA culture medium $(0.05 \mathrm{M}$ lactic acid $)$ with chitosan $\left(0.1-1 \mathrm{~g} \mathrm{~L}^{-1}\right)$. Spores from colonies of 10 days of growth were extracted with a sterile microbiological loop and inoculated to the center of the medium culture within the Petri dish. It was incubated at $25{ }^{\circ} \mathrm{C}$ and colony diameters were manually measured every $24 \mathrm{~h}$ until the colony covered $80-90 \%$ of the surface of the plate. Subsequently, logarithmic growth kinetics were obtained (logarithm of the radius of the colony vs. time), and the $\log$ phase (exponential growth) was later used to calculate the radial growth speed of this growth stage [44]. The log phase is the most suitable stage for testing the susceptibility of filamentous fungi to antifungal compounds [59]. Likewise, the percentage of radial growth inhibition of the acidified PDA treatment with chitosan $\left(0.1-1 \mathrm{~g} \mathrm{~L}^{-1}\right)$ was calculated with respect to the acidified PDA culture medium. Finally, the strains that showed sensitivity and resistance to chitosan were scored.

The experimental study design was completely randomized; the study factor was isolated fungi and culture media composition. Analyses of variance (ANOVA) and Tukey tests, with the significance level set at $p<0.05$, were carried out using JMP version 5.0 (SAS Institute Inc., Cary, NC, USA).

Author Contributions: Conceptualization and funding acquisition, E.A.Q.-O.; methodology and writing—original draft preparation, G.V.-O. and E.A.-H.; formal analysis of chitosan, J.L.-M.; conceptualization and writing-review and editing, M.Á.M.-T. and S.M.G.-C. Statics methodology and writing-review C.S.-M.-H. All authors have read and agreed to the published version of the manuscript.

Funding: This research and APC was funded by Consejo Nacional de Ciencia y Tecnología (FOSEC SEP-INVESTIGACIÓN BÁSICA; FSSEP02-C-2018-2), grant number A1-S-34064-“Respuestas transcriptómicas de complejos de Colletotrichum expuestos a nanopartículas de quitosano en un modelo in vitro".

Institutional Review Board Statement: Not applicable.

Informed Consent Statement: Not applicable.

Data Availability Statement: They can be requested from the corresponding author.

Acknowledgments: To CONACYT (Mexico) for the scholarship for graduate studies awarded to G.V.-O.

Conflicts of Interest: The authors declare no conflict of interest.

Sample Availability: Samples of the fungi isolates are available from the corresponding author. 


\section{References}

1. Herrera-González, J.A.; Bautista-Baños, S.; Salazar-García, S.; Gutiérrez-Martínez, P. Situación actual del manejo poscosecha y de enfermedades fungosas del aguacate 'Hass' para exportación en Michoacán. REMEXCA 2000, 11, 1647-1660. [CrossRef]

2. González-Álvarez, M.; Moreno-Limón, S.; Salcedo-Martínez, S.; Pérez-Rodríguez, E. In vitro Evaluation of Antifungal Activity of Agave (Agave scabra, Salm Dyck) Extracts against Post-Harvest Mushrooms. Phyton (B Aires) 2015, 84, 427-434.

3. García-Mateos, M.R.; Acosta-Ramos, M.; Rodríguez-Pérez, E.; Vásquez-Sánchez, J.; Hernández-Ramos, L. Extractos vegetales para el control de Colletotrichum gloeosporioides in vitro, en periodo de floración de Carica papaya. Polibotanica 2021, 51, 213-228.

4. Palou, L.; Montesinos-Herrero, C. Uso de fungicidas en poscosecha de frutos cítricos. Horticultura 2015, 321, 72-76.

5. Shahid, M.; Zaidi, A.; Rizvi, A.; Saif, S.; Ahmed, B. Recent advances in management strategies of vegetable diseases. In Microbial Strategies for Vegetable Production; Zaidi, A., Khan, M., Eds.; Springer: Cham, Switzerland, 2017; pp. 197-226.

6. Gan, H.; Wickings, K. Soil ecological responses to pest management in golf turf vary with management intensity, pesticide identity, and application program. Agric. Ecosyst. Environ. 2017, 246, 66-77. [CrossRef]

7. Mesa, A.M.; Marin, P.A.; Ocampo, O.; Calle, J.; Monsalve, F.Z.I. Fungicidas a partir de extractos vegetales: Una alternativa en el manejo integrado de hongos fitopatógenos. RIA 2019, 45, 23-30.

8. $\quad$ Landero-Valenzuela, N.; Lara-Viveros, F.M.; Nieto-Angel, D.; Aguado-Rodríguez, J.; Callejas-Hernández, J. Mulberry (Morus alba) leaf extracts as a control alternative of blue mold on postharvest apple fruit. Rev. Mex. Fitopatol. 2017, 35, 1-19.

9. Maia, T.F.; Donato, A.D.; Fraga, M.E. Review atividade antifúngica de oleos essenciais de plantas. Rev. Bras. Prod. Agroind. 2015, $17,105-116$.

10. Yari, O.M.; Morales, J.S.; Ramírez-Navas, J.S. Fungicidal effect of chitosan on rust inoculated on coffea. UGCiencia 2016, 22, 45-56.

11. Rios-Ruiz, C.A.; Bojórquez, V.G.; Cárdenas, R.A.; Mariscal, C.J.; Justo, L.A.C.; Nito, C.M.A.N. Chitosan as a fungicide from shrimp exoskeleton. Rev. Cienc. Tecnol. 2020, 3, 57-62.

12. Castañeda-Ramírez, J.; Laurel-Ángeles, V.; Espinoza-Zamora, J.; Salcedo-Hernández, R.; López-Ramírez, M.; De la Fuente-Salcido, N. Efecto del quitosano para el biocontrol de hongos fitopatógenos identificados molecularmente de frutas y hortalizas en Guanajuato. Investig. Desarro. Cienc. Tecnol. Aliment. 2016, 1, 207-213.

13. Hernández-Téllez, C.; Cortez-Rocha, M.; Burgos-Hernández, A.; Rosas-Burgos, E.; Lizardi-Mendoza, J.; Torres-Arreola, W.; Burboa-Zazueta, M.; Plascencia-Jatomea, M. Chitosan/carrageenan/lysozyme particles: Synthesis, characterization and antifungal activity against Aspergillus parasiticus. Rev. Mex. Ing. Quim. 2018, 17, 897-912. [CrossRef]

14. Rodríguez-Romero, V.M.; Villanueva-Arce, R.; Trejo-Raya, A.B.; Silvía, B.-B. Chitosan and Pseudomonas fluorescens extracts for Alternaria alternata control in tomato (Solanum lycopersicum). Mex. J. Phytopathol. 2019, 37, 202-219.

15. Berumen, G.V.; Coronado, L.D.P.; Ochoa, V.A.J.; Chacón, M.A.L.; Gutiérrez, P.M. Effect of chitosan on the induction of disease resistance against Colletotrichum sp. in mango (Mangifera indica L.) cv. Tommy Atkins. Investig. Cienc. 2015, $23,16-21$.

16. Bautista-Baños, S.; Ventura-Aguilar, R.I.; Correa-Pacheco, Z.; Corona-Rangel, M.L. Chitosan: A versatile antimicrobial polysaccharide for fruit and vegetables in postharvest-a review. Rev. Chapingo Ser. Hortic. 2017, 23, 103-121. [CrossRef]

17. SIAP (Servicio de Información Agroalimentaria y Pesquera). Panorama Agroalimentario 2020; Secretaria de Agricultura y Desarrrollo Social: Gobierno de México, México, 2020. Available online: https:/ / nube.siap.gob.mx/gobmx_publicaciones_siap/ (accessed on 11 August 2021).

18. Mendoza-Herrera, Y.M.; Rios-Velasco, C.; Cambero-Campos, J.; De dios-Ávila, N.; Pérez-Corral, D.A.; Rodríguez-Guerra, R.; Estrada-Virgen, M.O. Antagonistic actinomycetes to Colletotrichum sp. Penz in the mango cultivation in Nayarit, Mexico. Ecosistemas Y Recur. Agropecu. 2020, 7, 1-9.

19. Valdés, L.A.; Calero Consuegra, D.; Carballo, M.E.; Capote, M.; González, I.; Álvarez, J.M. Characterization morphological, cultural and pathogenic of isolated Colletotrichum sp. anthracnose producing in mango (Mangifera indica L.). La Granja Rev. De Cienc. De La Vida 2017, 26, 38-51. [CrossRef]

20. Lima, O.P.D.; de Oliveira, K.Á.R.; Dos Santos Vieira, W.A.; Câmara, M.P.S.; de Souza, E.L. Control of anthracnose caused by Colletotrichum species in guava, mango and papaya using synergistic combinations of chitosan and Cymbopogon citratus (D.C. ex Nees) Stapf. essential oil. Int. J. Food Microbiol. 2018, 266, 87-94. [CrossRef]

21. Dowling, M.; Peres, N.; Villani, S.; Schnabel, G. Managing Colletotrichum on fruit crops: A “complex" challenge. Plant Dis. 2020, 104, 2301-2316. [CrossRef]

22. Tovar-Pedraza, J.M.; Mora-Aguilera, J.A.; Nava-Díaz, C.; Lima, N.B.; Michereff, S.J.; Sandoval-Islas, J.S.; Camara, M.P.S.; TélizOrtiz, D.; Leyva-Mir, S.G. Distribution and pathogenicity of Colletotrichum species associated with mango anthracnose in Mexico. Plant Dis. 2020, 104, 137-146. [CrossRef] [PubMed]

23. Li, Q.; Bu, J.; Shu, J.; Yu, Z.; Tang, L.; Huang, L.; Guo, T.; Mo, J.; Luo, S.; Solangi, G.S.; et al. Colletotrichum species associated with mango in southern China. Sci. Rep. 2019, 9, 18891. [CrossRef] [PubMed]

24. Zakaria, L. Diversity of Colletotrichum species associated with anthracnose disease in tropical fruit crops. A review. Agriculture 2021, 11, 297. [CrossRef]

25. Arauz, L.F. Mango anthracnose: Economic impact and current options for integrated management. Plant Dis. 2000, 84, 600-611. [CrossRef] [PubMed]

26. Omar, N.H.; Mohd, M.; Nor, N.M.I.M.; Zakaria, L. Characterization and pathogenicity of Fusarium species associated with leaf spot of mango (Mangifera indica L.). Microb. Pathog. 2018, 114, 362-368. [CrossRef] [PubMed] 
27. Rakesh, A.; Mishra, J.P.; Prasad, R.; Sekhar, J.C.; Gupta, D.; Reddy, V.P.; Kumar, S. Isolation and in vitro evaluation of fungicides against Pestalotiopsis mangiferae causing grey blight of mango. J. Pharmacogn. Phytochem. 2020, 9, 1368-1370.

28. Niren, M.; Chandra, M.N. Evaluation of Media for growth and sporulation characteristics of postharvest pathogens Curvularia lunata and Pestalotiopsis mangiferae. Ann. Plant Sci. 2019, 27, 89-94.

29. Lim, L.; Mohd, M.H.; Zakaria, L. Identification and pathogenicity of Diaporthe species associated with stem-end rot of mango (Mangifera indica L.). Eur. J. Plant Pathol. 2019, 155, 687-696. [CrossRef]

30. Garg, N.; Singh, B.; Vaish, S.; Kumar, S.; Arora, S. Exploring microbial community diversity of mango leaf compost. Curr. Hortic. 2021, 9, 27-35. [CrossRef]

31. Verlee, A.; Mincke, S.; Stevens, C.V. Recent developments in antibacterial and antifungal chitosan and its derivatives. Carbohydr. Polym. 2017, 164, 268-283. [CrossRef]

32. Grande-Tovar, C.D.; Chaves-Lopez, C.; Serio, A.; Rossi, C.; Paparella, A. Chitosan coatings enriched with essential oils: Effects on fungi involved in fruit decay and mechanisms of action. Trends Food Sci. Technol. 2018, 78, 61-71. [CrossRef]

33. Zhou, Y.; Zhang, L.; Zeng, K. Efficacy of Pichia membranaefaciens combined with chitosan against Colletotrichum gloeosporioides in citrus fruits and possible modes of action. Biol. Control. 2016, 96, 39-47. [CrossRef]

34. Algam, S.A.; Elwagia, M.E. Evaluation of chitosan efficacy on tomato growth and control of early blight disease. Jordan J. Agric. Sci. 2015, 11, 27-36.

35. Dibona-Villanueva, L.; Fuentealba, D. Novel Chitosan-Riboflavin Conjugate with Visible Light-Enhanced Antifungal Properties against Penicillium digitatum. J. Agric. Food Chem. 2021, 69, 945-954. [CrossRef]

36. Peña, A.; Sánchez, N.S.; Calahorra, M. Effects of Chitosan on Candida albicans: Conditions for Its Antifungal Activity. BioMed Res. Int. 2013, 527549, 15.

37. Ai, H.; Wang, F.; Xia, Y.; Chen, X.; Lei, C. Antioxidant, antifungal and antiviral activities of chitosan from the larvae of housefly, Musca domestica L. Food Chem. 2012, 132, 493-498. [CrossRef] [PubMed]

38. Li, M.; Chen, X.; Liu, J.; Zhang, W.; Tang, X. Molecular weight-dependent antifungal activity and action mode of chitosan against Fulvia fulva (cooke). J. Appl. Polym. Sci. 2010, 119, 3127-3135. [CrossRef]

39. Jiangtao, W.; Hedong, W. Preparation of soluble p-aminobenzoyl chitosan ester by Schiff's base and antibacterial activity of the derivatives. Int. J. Biol. Macromol. 2011, 48, 523-529.

40. Hosseinnejad, M.; Jafari, S.M. Evaluation of different factors affecting antimicrobial properties of chitosan. Int. J. Biol. Macromol. 2016, 85, 467-475. [CrossRef] [PubMed]

41. Jinasena, D.; Pathirathna, P.; Wickramarachchi, S.; Marasinghe, E. Use of chitosan to control anthracnose on "Embul" banana. In Proceedings of the International Conference on Asia Agriculture and Animal, IPCBEE, Hong Kong, China, 2-3 July 2011; IACSIT Press: Singapore, 2011; Volume 13, pp. 56-60.

42. Nascimento, J.I.G.; Stamford, T.C.M.; Melo, N.F.C.B.; Nunes, I.d.S.; Lima, M.A.B.; Pintado, M.M.E.; Stamford, T.L.M. Chitosancitric acid edible coating to control Colletotrichum gloeosporioides and maintain quality parameters of fresh-cut guava. Int. J. Biol. Macromol. 2020, 163, 1127-1135. [CrossRef] [PubMed]

43. Ramos, B.L.R.; Stamford, T.C.M.; de Oliveira, K.Á.R.; Pessoa, A.D.M.P.; de Lima, M.A.B.; Pintado, M.M.E.; Câmara, M.P.S.; de Oliveira Franco, L.; Magnani, M.; de Souza, E.L. Chitosan produced from Mucorales fungi using agroindustrial by-products and its efficacy to inhibit Colletotrichum species. Int. J. Biol. Macromol. 2018, 108, 635-641. [CrossRef] [PubMed]

44. Quintana-Obregón, E.A.; Plascencia-Jatomea, M.; López-Cervantes, J.; Cira-Chávez, L.A.; Sánchez-Machado, D.I.; Cortez-Rocha, M.O. Antifungal activity of chitosan in Cladosporium cladosporioides isolated from safflower. Rev. Mex. Mic. 2011, 34, 93-96.

45. Walker, G.M.; White, N.A. Introduction to Fungal Physiology. In Fungi: Biology and Applications, 3rd ed.; Kavanagh, K., Ed.; John Wiley \& Sons, Inc.: Hoboken, NJ, USA, 2017; pp. 1-35.

46. Hu, M.-J.; Grabke, A.; Schnabel, G. Investigation of the Colletotrichum gloeosporioides species complex causing peach anthracnose in South Carolina. Plant Dis. 2015, 99, 797-805. [CrossRef] [PubMed]

47. Sarkar, A.K. Anthracnose diseases of some common medicinally important fruit plants. J. Med. Plants 2016, 4, $233-236$.

48. Jiang, J.; Zhai, H.; Li, H.; Wang, Z.; Chen, Y.; Hong, N.; Wang, G. Chofong, G.N.; Xu, W. Identification and characterization of Colletotrichum fructicola causing black spots on young fruits related to bitter rot of pear (Pyrus bretschneideri Rehd.) in China. Crop Prot. 2014, 58, 41-48. [CrossRef]

49. Villafana, R.T.; Rampersad, S.N. Diversity, structure, and synteny of cutinase gene of Colletotrichum species. Ecol. Evol. 2020, 10, 1425-1443. [CrossRef] [PubMed]

50. Fuentes-Aragón, D.; Guarnaccia, V.; Rebollar-Alviter, A.; Juárez-Vázquez, S.B.; Aguirre-Rayo, F.; Silva-Rojas, H.V. Multilocus identification and thiophanate-methyl sensitivity of Colletotrichum gloeosporioides species complex associated with fruit with symptoms and symptomless leaves of mango. Plant Pathol. 2020, 69, 1125-1138. [CrossRef]

51. Nei, M.; Kumar, S. Molecular Evolution and Phylogenetics; Oxford University Press: Oxford, UK, 2000; pp. 147-163.

52. Khan, T.A.; Peh, K.K.; Ch'ng, H.S. Reporting degree of deacetylation values of chitosan: The influence of analytical methods. J. Pharm. Pharm. Sc. 2002, 5, 205-212.

53. Brugnerotto, J.; Lizardi, J.; Goycoolea, F.M.; Argüelles-Monal, W.; Desbrieres, J.; Rinaudo, M. An infrared investigation in relation with chitin and chitosan characterization. Polymer 2001, 42, 3569-3580. [CrossRef]

54. Seo, S.; King, J.M.; Prinyawiwatkul, W. Simultaneous depolymerization and decolorization of chitosan by ozone treatment. Food Sci. 2007, 72, C552-C556. [CrossRef] [PubMed] 
55. Badawy, M.E.; Rabea, E.I. A biopolymer chitosan and its derivatives as promising antimicrobial agents against plant pathogens and their applications in crop protection. Int. J. Carbohydr. Chem. 2011, 460381, 1-30. [CrossRef]

56. Solomon, O.F.; Ciută, I.Z. Détermination de la viscosité intrinsèque de solutions de polymères par une simple détermination de la viscosité. J. Appl. Polym. Sci. 1962, 6, 683-686. [CrossRef]

57. Seuvre, A.M.; Mathlouthi, M. Solutions properties and solute-solvent interactions in ternary sugar-salt-water solutions. Food Chem. 2010, 122, 455-461. [CrossRef]

58. Rinaudo, M. Chitin and chitosan: Properties and applications. Prog. Polym. Sci. 2006, 31, 603-632. [CrossRef]

59. Meletiadis, J.; Meis, J.F.G.M.; Mouton, J.W.; Verweij, P.E. Analysis of Growth Characteristics of Filamentous Fungi in Different Nutrient Media. J. Clin. Microbiol. 2001, 39, 478-484. [CrossRef] [PubMed] 